
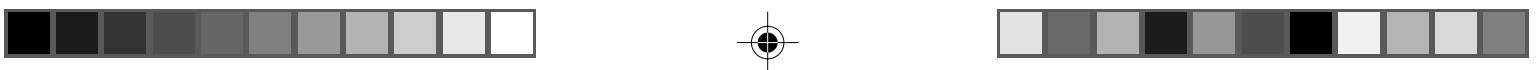

\title{
UDSIGELSE OG KULTURMØDER \\ Om sammenhængen mellem postkolonial litteratur og ansættelse af nydanskere
}

\author{
HEIDI BOJSEN
}

Når man læser postkolonial litteratur, altså litteratur, der beskriver koloniale samfund eller samfund, hvor kolonitidens konsekvenser indgår som en tydelig del af betydningsdannelsen, kan det undertiden være vanskeligt at identificere, hvilket kulturelt normsæt de forskellige udsagn og handlinger refererer til eller opstår ud af. Denne problemstilling kendes også andre steder fra. Enhver, der har prøvet at træde ind i eller arbejde sammen med en international organisation eller virksomhed, ved også, at det kan være vanskeligt, men nødvendigt, at få klargjort, om bestemte normer og begreber forstås og bruges på samme måde som i fx Danmark, USA, Kina eller Ghana. Problemet med at forstå, hvordan andre mener det, de siger, er ikke blot relevant $i$ arbejdet med litteratur, men er en del af vores hverdag og relevant i enhver form for kommunikation. Når nye ideer og ord skal introduceres på en arbejdsplads, skal de også oversættes. De skal formidles på en måde, der $\mathrm{g} ø \mathrm{r}$, at de bliver accepteret og anvendt af relevante medarbejdere på den mest hensigtsmæssige måde. En lignende oversættelsesproblematik er til stede, når en ny medarbejder skal ansættes, især hvis vedkommende skiller sig ud fra den bestående arbejdsskare. Vi kender problematikken i forhold til alder, køn og uddannelsesmæssig baggrund, fx når kvinder har skullet ind i mandefag, humanister ind i den private sektor eller ældre starte og oplæres i nye job. Seneste skud på stammen er ansættelsen af folk med anden etnisk eller religiøs baggrund end dansk eller sekulær, hvor især folk med en baggrund fra ikke-vestlige og muslimske kulturkredse synes at have vanskeligt ved at få fodfæste på det danske arbejdsmarked (Nygaard 2004:54-5), muligvis fordi de finder det vanskeligt at bryde gennem en mur af forbehold eller skeptiske forestillinger om, hvad en muslim er. ${ }^{1}$

Mit ærinde i denne sammenhæng er at præsentere nogle analytiske begreber, der kan hjælpe os til at forstå og håndtere kulturmøder. Jeg vil hovedsageligt arbejde ud fra to eksempler, der begge illustrerer kulturmøder mellem forskellige 

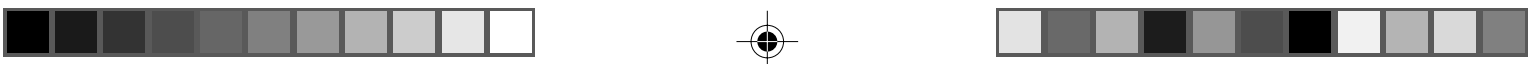

etniske grupper. Men lad os for en ordens skyld slå fast, at 'kulturmøder' også kan referere til møder mellem by- og landkultur, religiøs og ateistisk kultur, mellem forskellige sociale klassekulturer, mellem forskellige virksomhedskulturer, foreningskulturer osv.

I det første eksempel henviser jeg til en roman af den ivorianske forfatter Ahmadou Kourouma (1927-2003) og i det andet til en beretning om en jobsamtale, publiceret i en udgivelse af Arbejdsmarkedsafdelingen, Århus Kommune (Loveless 2003). Eksemplerne er valgt ud fra det kriterium, at de viser en gengivelse og fortolkning af vanskelighederne ved et kulturmøde. Jeg går her ikke op i, om gengivelserne og fortolkningerne er sandfærdige, men anvender dem udelukkende som mulige scenarier for, hvordan kulturmøde kan foregå og opfattes, for derefter at vise, hvordan de udvalgte analytiske begreber kan rejse spørgsmål og dermed give indsigt i kulturmøder. Sammenstillingen af fiktion med nonfiktion bunder i, at jeg ønsker at give et bud på, hvilken form for viden og ideer om kulturmøder litteratur kan byde på, og at vise hvordan sådanne ideer kan bruges i 'det virkelige liv'. Den litterære tekst betyder på andre præmisser end nonfiktion gør. Det vil sige, at den konstruerer social, kulturel og historisk betydning, nogen gange på de samme måder, men altid også på andre måder end nonfiktion. Alligevel er der interessante og lærerige paralleller - også på langt flere niveauer, end jeg kan nå at komme ind på her.

Da jeg ønsker at se på, hvordan tekster og udsagn betyder, har jeg valgt at tage fat i begrebet ,udsigelse“, der refererer til, hvordan tekstens udsagn udsiges, dvs. kommer til syne og skaber betydning i teksten. Det anvendes mest i lingvistikken og indgår i litteraturanalyse i forbindelse med beskrivelser af den narratologiske stil, hvor man blandt andet ser på tid og tempus, sted, aspekt, anvendelse af pronominer, direkte, indirekte og dækket direkte tale, synsvinkel, fortællerinstans osv. Går man imidlertid tilbage til en af de vigtigste teoretikere inden for udsigelsesanalysen, Emile Benveniste, bliver vi mindet om, at udsigelsen altid udfolder sig med reference til en pragmatisk konsensus mellem de talende. Hos Benveniste handler den pragmatiske konsensus ikke kun om sprogets indre logik som et lukket system, men om hvad man siger hvornår og om forholdet mellem signifiant og signifié (Benveniste 1966:82). Set i lyset af de mangeartede erfaringer, man kan gøre sig i forhold til kulturmøder, er etableringen af en pragmatisk konsensus om, hvordan udsagn skal forstås, ikke blot en teoretisk overvejelse, men ofte en konkret kilde til misforståelser, strid og forhandlinger, ny erkendelse og mulig udvidelse af ens begrebsapparat. Angivelse af tid og sted er klassiske eksempler på, at direkte oversatte adverbialer kan have vidt forskellige referenter i den sociale virkelighed. Hvornår er 'om lidt'? Hvor er 'hjemme'? Men der er også andre eksempler: Er ordet nègre en henvisning til et socialt identitetsfællesskab i 

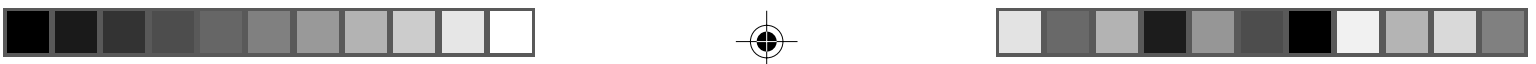

en frankofon kontekst eller et nedladende angreb? Er ordet 'neger' i Astrid Lindgrens børnebøger racistisk, og betyder det egentlig helt det samme som nègre eller som negroe?

Efter en præsentation af mine eksempler vil jeg introducere en række begreber, som jeg blandt andet henter fra litteraturkritikere som Mikhail Bakhtin, Edward Said og Homi Bhabha samt fra idehistorikeren og filosoffen Michel Foucault. Min diskussion vil så vidt muligt fokusere på, hvilken indsigt de anvendte begreber kan give, dvs. hvilke spørgsmål de rejser. Min interesse for den praktiske anvendelighed gør, at jeg har valgt at lade artiklen munde ud i nogle foreløbige overvejelser over, hvordan man kan drage nytte af at gribe kulturmødet analytisk an - især med reference til det sidste af mine eksempler.

\section{Eksempel I. Administrativ implementering af kolonipolitik: et karikeret kulturmøde}

Den prisbelønnede ivorianske forfatter Ahmadou Kourouma har i sin roman Monnè, outrages et défis (1990) (Monnè, fornedrelser og udfordringer) nogle underfundige eksempler på, hvordan forskellige franske begreber som 'civilisation', 'tvangsarbejde', 'afgifter', 'sekularisme' og 'assimilation' er nærmest uoversættelige i kolonitidens Mali (historien udspiller sig i perioden fra 1890'erne til 1950 'erne). Romanens hovedperson, kongen Djigui, vælger konsekvent det franske sprog fra, blandt andet fordi udtalen af flere ord i påfaldende grad lyder som obskøne udtryk på hans eget sprog. Da ordene tilmed er vanskelige at udtale, oversættes de indimellem til malinkéord eller neologismer på begge sprog.

En af de koloniadministratorer, vi møder i bogen, hedder Héraud, og han forsøger igennem hele sin karriere at indgå i dialog og forståelse med malinkéfolket, blandt andet ved at lære deres ordsprog, uden dog på noget tidspunkt at tvivle på det kolonialistiske projekts berettigelse. Efter 2. Verdenskrig indfører Frankrig officielt assimilation som koloni-politik. At Frankrig overhovedet bliver i stand til at organisere og mobilisere væbnet modstand mod den tyske besættelsesmagt, skyldes som bekendt, at det lykkes franskmænd og afrikanere at nedkæmpe det franske samarbejdsregimes støtter i de afrikanske kolonier, hvorved Brazzaville kan fungere som de Gaulles base under krigen. Afrikanernes betydelige engagement i krigen gør, at kolonipolitikken må gentænkes ved krigens afslutning.

Assimilationspolitikken går officielt ud på at knytte kolonierne tættere til Frankrig i en form for føderation. Mali og de andre kolonier indgår nu i l'Union française og kaldes departementer eller territorier. Tvangsarbejde ophæves, der indføres forsamlingsfrihed, og afrikanske repræsentanter kan nu vælges til det franske parlament i et større antal end den ene, men celebre forgænger, Blaise 

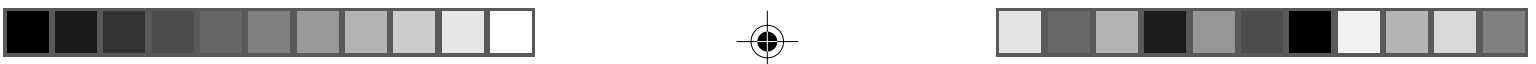

Diagne, der havde arbejdet bravt for øget assimilation i 1930'erne med det formål at sidestille afrikanerne med franskmændene. Afrikanernes status er ændret, men alligevel er der ikke tale om en reel lighed eller sidestillelse med de franske medborgere. Der etableres nemlig et tokammersystem, gennem hvilket franskmænd beholder uforholdsmæssig stor magt over hele unionen. Systemet gør, at afrikanerne får under 30 pladser ud af de over 600 i nationalforsamlingen. Samtidig slås der stadig hårdt og voldeligt ned på demonstranter - det værste eksempel finder sted mod frihedsbevægelsen i Madagaskar i 1947-48, hvor 80-100.000 mennesker bliver dræbt, skønt bevægelsen ikke ønskede frigørelse fra unionen, men blot fra en undertrykkende lovgivning (Dozon 2003:194). Med andre ord er afrikanernes status under assimilationen i 1940'erne og 1950'erne meget ambivalent. På den ene side omtales de som brødre i den franske union, på den anden side har de på mange måder stadig status som sujets, den juridiske term, der adskiller dem fra citoyens, dvs. franskmænd og 'civiliserede' afrikanere, der anses som værdige til at opnå statsborgerskabet.

Tvetydigheden i hvad assimilationen egentlig indebar af selvmodsigelser, er blevet belyst flere gange af førende forskere inden for feltet. ${ }^{2}$ En af de meget lovende forskere inden for området er Emmanuelle Saada, der har grader i historie og sociologi fra ENS og EHESS og nu er lektor ved Columbia University. Saada belyser i sin forskning, hvordan man i politiske debatter og i lovgivningsarbejdet igen og igen lægger vægt på, at de koloniserede og senere les sujets skal gøre sig fortjent, vise sig værdige, til at blive indlemmet i det privilegerede samfunds rækker (Saada 2003). Der er slående ligheder i mellem dele af hendes eksempelmateriale og den diskurs, man hører i integrationsdebatter rundt om i Europa, og det kan måske også forklare, at en gruppe aktivister i Frankrig i januar 2005 protesterede mod indvandreres og etniske minoriteters sociale levevilkår i Frankrig ved at sammenligne dem med de koloniseredes inden dannelsen af den franske union i 1946. Bevægelsens navn, Les indigène de la République, henviser til, at de skulle være republikkens 'indfødte' - altså de uværdige, der ikke var værdige til civilisationens velsignelser. I deres første erklæring hedder det blandt andet: „Man nægter de, der ikke er 'franske', retten til at stemme, samtidig med at man betvivler 'tilhørsforholdet' hos dem, der er det. ${ }^{\text {“3 }}$ Analogien er ganske vist en del forfejlet, fordi historiske og juridiske omstændigheder dengang og nu er vidt forskellige. Men magtesløsheden over for den åbenlyse forskel, der er mellem, hvad loven og politiske erklæringer siger, den gør på den ene side, og hvad folk så oplever i praksis på den anden, er en lighed mellem dengang og nu, der er reel og sværere at afvise. Det, som den tvivlsomme analogi med den vigtige pointe hos de franske aktivister og Kouroumas eksempler har til fælles, er, at de henviser til, hvordan oversættelse af vigtige begreber i kulturmøder altid må tænkes i forhold 

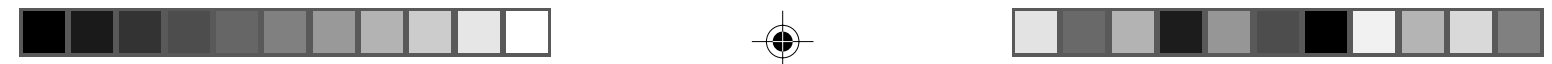

til den betydning, som ordene synes at have i praksis. I sidste ende er det nemlig praksis og folks konkrete erfaringer med ordene, der skaber deres betydning. Set ud fra denne vinkel bliver anførselstegnene i citatet interessante, fordi de henviser til bevægelsens erfaringer med, hvad 'franskmand' og 'tilhørsforhold' egentlig betyder i forhold til etnisk oprindelse. Det franske ord for 'tilhørsforhold' - enracinement - betyder i sin mest konkrete betydning 'rodfæstelse' og gør den implicitte vurderinger af mennesker ud fra etniske tilhørsforhold endnu tydeligere.

I Kouroumas fortælling skal Héraud nu ved hjælp af en malinkétolk forsøge at forklare Djigui, hvad assimilation er. En af romanens kvaliteter er, at den hele vejen igennem er beskrevet ud fra malinkébefolkningens synspunkter og erfaringer. Langt den overvejende del af fransksproget litteratur af afrikanske forfattere udkommer på forlag i Paris, og læserskaren er fransk og frankofon. Så selv om perspektivet er malinké, må der alligevel skabes en form for pragmatisk konsensus med de ikke-afrikanske læsere. En yderligere finesse ligger i det forhold, at bogen indeholder budskaber, humor og ironi, som især har den afrikanske del af læserskaren for øje. Man kan indimellem fornemme, hvordan Kourouma og den afrikanske læser småler sammen over den ikke helt indviede - dvs. ofte, men ikke nødvendigvis kun og altid europæiske-læsers stereotype forestillinger, som fortællingen både imødegår og alligevel blotlægger. Dette er medvirkende til, at romanen får formidlet en overordnet og særdeles vellykket problematisering af flere europæisk forankrede historieopfattelser og af både afrikanske og europæiske prætentioner om at kunne løsrive historiografien fra den sociale kontekst, den betyder noget $\mathrm{i}$.

Selve ordet 'assimilation' fremkommer aldrig i teksten. I stedet får vi udtrykket hiriasson, der ikke har nogen præcis betydning på malinké, men hvis endelse -son betyder 'en forbigående ulykke'. Héraud bliver på et tidspunkt kaldt til Frankrig og siger til afsked: "Jeg vender tilbage til Soba, enhver reaktion [på assimilationen] vil indgå som en begivenhed i historiens forløb" (Kouroma 1990: 262). Hvor Héraud hentyder til assimilationens og den fremadskridende histories uafvendelighed, ser Djigui og hans folk hans udsagn som en bekræftelse på, at assimilation blot er en forbigående ulykke.

Et andet vanskeligt ord er 'sekularisme', der under tolkens anstrengelser bliver til sigui ya son, der betyder 'sæt dig ned og vent'. I en fransk kontekst er sekularisme tæt forbundet med en magtpolitisk kamp mellem kirke og stat, der i 1905 førte til adskillelsen som et fredsskabende kompromis, men i en vestafrikansk kontekst giver det ikke mening, da der ikke har været de samme konflikter. Inden assimilationspolitikkens indførelse har kolonimagten tilmed ofte valgt at arbejde tæt sammen med muslimske ledere, fordi de derved bedre kunne opnå social 

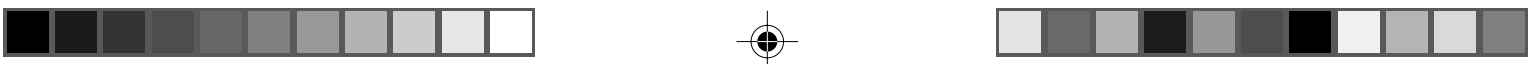

kontrol over befolkningerne. Sammen med oversættelsen af 'assimilation' vurderer Djigui, at den rette reaktion må være at sætte sig ned og bede Allah om nåde og vente på, at den forbigående ulykke passerer (ibid.). Ironisk nok kommer implementeringen af sekularisme og assimilation til at betyde $\varnothing$ get religiøs fordybelse, men ingen fremfarende politisk handling. For europæerne ligner det passivitet og resignation, men for malinkébefolkningen er der tale om en rationel og værdig reaktion på situationen.

Uagtet at hans eksempler er opdigtede, viser Kouroumas fortællinger os en social dynamik, der giver os indsigt i vanskelighederne ved kulturel oversættelse. Er her 'blot' tale om et møde mellem modernitet og tradition, sådan som en del kritikere har set Kouroumas og andre afrikanske forfatteres tekster? ${ }^{4}$ Er det en beskrivelse af det umulige kulturmøde?

\section{E ksempel II. J obinterview: et karikeret kulturmøde}

Ethvert jobinterview er en form for kulturmøde, men vi bliver som oftest først rigtigt opmærksomme på det, når jobkandidaten er væsentligt anderledes på et eller flere punkter end andre kandidater eller de ansatte, der allerede er på en given arbejdsplads. Abi Barmi kom til Danmark fra Iran i midten af 1980'erne. Trods danske uddannelser som teknisk assistent og bygningsingeniør har han ikke kunnet få job i noget dansk firma. Han har prøvet at starte sit eget op, men måtte lukke det ned. Hans historie på arbejdsmarkedet indeholder en lang række jobansøgninger, aktiveringstiltag, et par enkelte samtaler. I 2000 får han så endelig job som værkstedsassistent hos Job og Miljø under Århus Kommune og bliver kort efter arbejdsleder. I artiklen publiceret af Århus Kommune fortæller han om de folk, der ikke har haft held til at finde et job, og som derfor kommer i værkstedet. De er ofte veluddannede, som fx en kemiingeniør med udenlandsk baggrund.

Desuden fortæller Barmi om den første gang, han endelig blev kaldt til samtale efter 110 forgæves ansøgninger om en praktikplads som teknisk assistent. Første samtale hos den overordnede chef i København gik godt, og han blev praktisk talt lovet jobbet mundtligt. Nu skulle han blot til samtale hos den lokale chef $\mathrm{i}$ Århus, hvor han skulle arbejde, men der gik det helt anderledes:

\footnotetext{
'Der sad tre mennesker og udspurgte mig. De ville vide, om jeg var muslim, om jeg bad, og om jeg spiste svinekød. Det handlede overhovedet ikke om mig - de så ikke en gang på mine opgaver og tegninger!'

Abi blev vred og gik. Næste dag fortsatte seancen - denne gang med fem personer omkring bordet. 'De havde haft en medarbejder, som bad fem gange om dagen. Men det var da ikke mit problem. Jeg er ikke troende!' (Loveless 2003)
} 

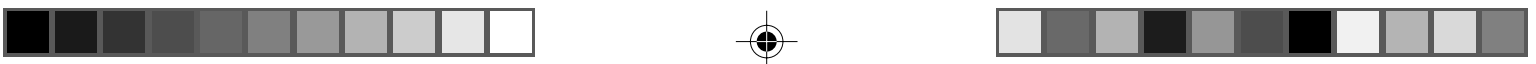

Hvordan kan man analysere denne hændelse? Hvilken erfaring kan man drage af den som virksomhedsleder, rekrutteringsleder eller nydansker på jagt efter job?

Eksemplet er interessant, fordi der her er to forestillingsverdener, der mødes. På den ene side har vi Barmi, der har et langt uddannelsesforløb bag sig og over hundrede afslag uden et eneste jobinterview. På den anden side har vi nogle repræsentanter fra en virksomhed, der åbenbart har én dårlig erfaring med en muslimsk ansat, hvor bønnen blev anset som problematisk.

Vi kan nu vælge at gribe en sådan situation an på forskellig vis. Man kan vælge en juridisk vinkel, hvor det klart vil fremstå, at der har været tale om diskriminerende spørgsmål, idet madvaner og religion ikke er relevant for varetagelsen af et job som teknisk assistent. Med hensyn til tid til at bede kunne man sige, at det ikke tager mere tid end at ryge en cigaret, men at det måske af praktiske årsager - fx på grund af tidspunkterne eller pladsforhold - er uhensigtsmæssigt, akkurat som med en ryger. Ville man behandle en kvindelig jobkandidat på samme måde, hvis man havde en dårlig erfaring med en, der læste i Alt for damerne fem gange om dagen i arbejdstiden? Eller en jobkandidat med børn, fordi én tidligere ansat havde haft syge børn endog meget tit eller sendte dem sms'er fem gange om dagen?

Frem for at pege en anklagende juridisk finger på rekrutteringspersonalet kan man også stille sig nogle analytiske spørgsmål, der kan hjælpe med at forstå en handling, der tilsyneladende er i modstrid med virksomhedens interesse. For det lader til, at rekrutteringen ikke har taget udgangspunkt i et givent match mellem jobfunktion og kandidatens faglige kvalifikationer, som alle HR-managementbøgerne ellers belærer os om. Derudover synes én dårlig erfaring med en medarbejder at være et meget spinkelt erfaringsgrundlag at argumentere ud fra.

Hvad får rekrutteringspersonalet til at sammenligne Barmi med den tidligere ansatte, når Barmi ikke er troende? Og hvordan er det muligt, at det religiøse kommer til at fylde så meget $\mathrm{i}$ et interview med en ikke-troende kandidat? På en arbejdsplads, der slet ikke arbejder med noget religiøst? Og hvorfor får Barmi ikke gjort det klart, at han ikke er troende, og får drejet samtalen ind på faglige emner? Er her tale om et umuligt kulturmøde?

Inden vi vender tilbage til disse spørgsmål, må vi først have afklaret, hvordan vi kan tale om et kulturmøde. I det følgende vil jeg præsentere begreber som udsigelsesagens, kontrapunktisk udsigelse, diskursive formationer og tegnets anterioritet. Alle begreberne handler om betydningsdannelse, altså om hvordan udsagn betyder i en given sammenhæng. ${ }^{5}$ Den metodiske vægtning af udsigelsen frem for identitetskategorier sker ud fra den betragtning, at et kulturmøde, for at det kan opfattes og begrebsliggøres som et sådant, indebærer fortolkning og udtryk som følge af den observation og eventuelle kommunikation, der har fundet sted 

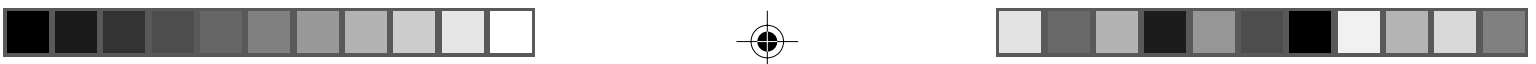

mellem de mødende parter. Netop graden og formen af en eventuel kommunikation i mødet er afgørende for, hvordan kulturmødet efterfølgende fortolkes og begrebsliggøres og dernæst bruges til at præcisere, omformulere eller bekræfte forskellige identitetskategorier.

\section{Kontrapunktisk udsigelse}

I narratologisk teori opererer man undertiden med begrebet 'udsigelsessubjekt'. Men ordet 'subjekt' er vildledende, for modsat et udsagnssubjekt er her ikke tale om en fastlagt referent eller en person, men om et abstrakt begreb. Som den franske lingvist Oswald Ducrot anfører, så kan udsagnssubjektet ikke være identisk med udsigelsessubjektet. Hver gang en fortæller i en litterær fortælling påtager sig rollen som udsiger, vil der stadig være en anden 'instans', der fungerer som subjekt for udsigelsen (Ducrot 1984:412-3).

Men denne redegørelse holder fast i ideen om et subjekt, selv om der reelt set henvises til en abstrakt form for agens. Det er på denne baggrund, at jeg mener, at man i stedet med fordel kan anvende neologismen 'udsigelsesagens'. Fordelen er, at der ikke længere antydes en personificeret eller entydig styring af, hvordan betydningen skabes i teksten, og af hvordan udsagnene udsiges. En anden fordel er, at begrebet 'agens' åbner op for, at man kan indtænke andre parametre for, hvordan betydning dannes, end de gængse, sådan som de er redegjort for i lingvistikken og litteraturanalysen, hvoraf jeg har angivet nogle ovenfor.

Barmi og Djigui er udsagnssubjekter, men ikke udsigelsessubjekter. Ved at tale om udsigelsesagens har vi mulighed for at vise, hvor og hvordan deres udsagn rent faktisk kan påvirke, om end ikke styre og kontrollere, den måde, de kulturmøder, de oplever, foregår på. For eksempel kan de med deres udsagn kaste nogle andre konsensuspræmisser på banen end dem, deres samtalepartnere taler ud fra. Af forskellige grunde og med forskellige hensigter og resultater. Som vi har set, risikerer man let at støde den anden fra sig eller at virke obskur.

På et overordnet plan kan forfatteren til henholdsvis romanen og artiklen vælge at lade bestemte udsagn fremstå i overensstemmelse med eller i modsætning til tekstens fremherskende udsigelsesform og -rationale. I romanen er kun malinkéfolkets synsvinkel direkte tilgængelig, og i artiklen er det kun Barmis udlægning, vi kender. Alligevel kan vi få en idé om henholdsvis kolonialisternes og rekrutteringspersonalets forestillingsverdener - ideer, der kan afvises eller underbygges ved at inddrage yderligere materiale.

I sin bog om litteraturanalyse i en postkolonial kontekst, Culture and Imperialism (1993), understreger litteraturkritikeren Edward Said eksplicit den heuristiske nødvendighed af at undgå 'bebrejdelsernes retorik' og opfordrer i stedet til en 

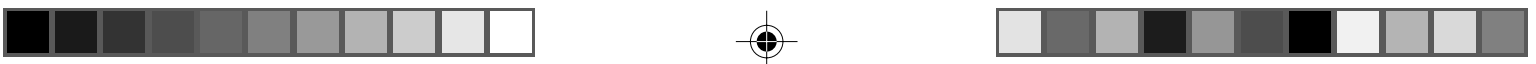

kontrapunktisk læsning af litteratur og postkoloniale tekster (Said 1994:19, 37, 115). Ligesom kontrapunktet i musikken indikerer, hvordan et givent tema gengives af forskellige stemmer under skiftende betoning, bruger Said det til at påpege, at en kontrapunktisk læsning inddrager flere modsatrettede eller forskellige repræsentationer af et givent tema eller sted i teksten. Man bør fx også kigge uden for teksten og lade andre perspektiver spille op imod og sammen med det, som fortællingen selv fremstiller som vigtigt, for derved at tydeliggøre, hvordan teksten skaber betydning og bliver meningsfuld på sin helt egen facon. ${ }^{6}$

I mit arbejde med frankofone postkoloniale romaner har jeg imidlertid fundet, at kontrapunktmetaforen kan bruges til mere end at beskrive en læsestrategi. Nogle af romanerne er faktisk kontrapunktiske i deres udsigelsesform, dvs. i måden, teksten overordnet set skaber betydning på. Dette er ofte med til at gøre dem interessante, både hvad angår den litterære æstetik og den potentielle erkendelsesberigelse, som de har at byde på (Bojsen 2006). I denne sammenhæng bør det understreges, at det kontrapunktiske ikke blot består i, at flere forskellige og eventuelt modsatrettede udsagn kommer frem i teksten, men at der i teksten forefindes flere forskellige logikker om tid, sted, sandhed og væren, som altså styrer de forskellige udsagns betydningsdannelse.

For at kunne dokumentere denne påstand er det nødvendigt at konkretisere de vilkår, som betydningsdannelsen sker under. Der er flere veje at gå, og jeg vælger her først kort at skitsere nogle ideer fra to teoretikere, nemlig Mikhail Bakhtin og Michel Foucault.

\section{Social flersprogethed og diskursive formationer}

Bakhtins romanteori komplementerer Benvenistes arbejde og udsigelsesteori generelt på flere punkter. Bakhtin taler blandt andet om le langage commun, et fælles sprog, som en forfatter anser for at referere til fælles perspektiver og begrebsliggørelser af mennesker og genstande i en given del af samfundet, altså til et fælles værdisæt (Bakhtin 1978:123). Bakhtins kendte polyfonibegreb implicerer, at dette fælles sprog (og dermed den dertil hørende pragmatiske konsensus) ikke kan tages for givet: Sproget er ikke et neutralt miljø. Den talende kan ikke tilegne sig det i al frihed og uden en vis vanskelighed. Det er befolket, ja, overbefolket af fremmede intentioner. At overvinde og undertvinge disse intentioner ens egen vilje og ønsker er en krævende og kompleks proces (op.cit. 115).

Romanpersonernes modsatrettede eller samstemmende intentioner er badet $\mathrm{i}$ social flersprogethed (plurilinguisme social), mener Bakhtin, og må derfor gentolkes og oversættes af den enkelte. Individet bærer disse modsætninger i sig, men de er kun toppen af det 'underliggende ocean', der er 'i oprør', og som fyl- 

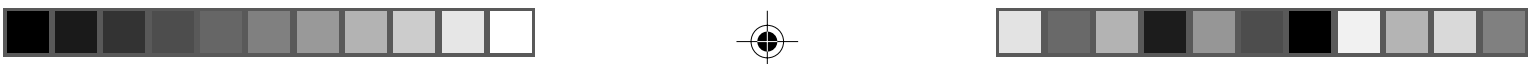

der personernes bevidsthed og tale med sin fundamentale flersprogethed (op.cit. 146). Dermed bærer personernes udsagn betydninger i sig, som ligger ud over deres egne eksplicitte intentioner.

Ved hjælp af Bakhtin kan vi altså ane, at et givent udsagn potentielt set kan siges på kontrapunktisk vis, hvis altså de forskellige intentioner får lov til at udfolde sig på samme tid. Samtidigt må vi sige, at denne flersprogethed er en del af en teksts udsigelsesagens. Vi har imidlertid stadig brug for at blive mere præcise.

Det er her, jeg mener Foucault bliver relevant. I Archéologie du savoir (1969) (Vidensarkceologien, 2005) definerer han diskursive formationer som de tilfælde, hvor udsagn indordner sig i en fælles betydningsdannelse, ved at der mellem genstande, udsigelsesformer, begreber og valg af emner fremstår en form for regelmæssighed (Foucault 1969:53). Diskursive formationer forudsætter altså, at der er en funktionel pragmatisk konsensus om, hvad man siger hvornår og hvordan. Samtidig er de også med til at fastholde og understøtte en given fælles forståelse. Et eksempel på en diskursiv formation kan fx være samspillet mellem handlinger, ord og objekter, der alle underst $\varnothing$ tter ideen om nationalstaten og kolonialisme som en nødvendig og universelt fremragende og naturlig organisering af social orden. En anden kan være, at islam er uforenelig med og ikke en del af den kulturelle virkelighed i Danmark, dvs. af dansk kultur. Diskursive formationer er historiske. Som Foucault siger, kan man ikke sige hvad som helst når som helst i historien (op.cit. 61). Men de faktiske betingelser og muligheder, der er gemt i dette 'kan man', er for mig at se et underkendt grundvilkår i kortlægningen af den litterære teksts udsigelse, men også i andre tekster, sådan som jeg har antydet det i anden sammenhæng (Bojsen \& Larsen 2003).

Ud over at vi må se på samspillet mellem diskursive formationer, social flersprogethed og intentioner, må vi anerkende et socialt og handlende subjekt, der kan forholde sig refleksivt og kreativt til sproget og de diskursive vilkår, og som altså også - i princippet - har mulighed for at påvirke dem, selv om det aldrig kan handle eller tænke sig uden for sproget og alle diskurser. Det sker jo igen og igen, at vi støder på udsagn, der støder imod eller falder uden for den diskursive formation, de indskriver sig i. Ofte er det udtryk for, at en anden forestilling eller logik, muligvis med en anden diskursiv formation i bagagen, trænger sig på. Når Djigui vælger at konfrontere assimilation og sekularisme med at sætte sig ned og med bøn vente på, at den forbigående ulykke passerer, laver han et umiddelbart brud med den kolonialistiske diskursive formation, der dikterer, hvad assimilation og et sekulært samfund går ud på, og som jo refererer til europæiske forståelser af politisk og social modstand. Set fra hans eget udgangspunkt giver denne tilsyneladende irrationelle handling mening i den diskursive sociale og politiske formation, der indebærer, at Allah sørger for dem, der tror på ham, og som bekræftes 

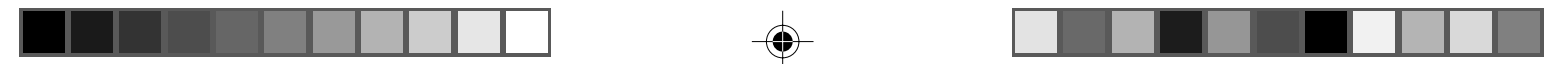

af den sproglige fortolkning af de franske begreber. Rundt om i det omgivende samfund er der mange institutioner, love, fortællinger, religiøse ledere og familieoverhoveder for ikke at glemme den obligatoriske griot (der ikke så meget er en 'heksedoktor' som en blanding mellem en spindoktor, journalist og historiekronikør, da hans funktion er at sikre, at kongen tager sig rigtigt ud i den offentlige polemik og historieoverlevering), der alle understøtter og indgår som en del af denne diskursive formation, som derfor forekommer at være helt legitim og logisk i malinkésamfundet. Fælles for alle er, at et sekulært samfund simpelthen ikke blot er utænkeligt, men ganske enkelt ubegribeligt, en absurd umulighed, der ikke engang giver en provokatorisk mening. Romanens fortælling er konstrueret på en måde, der viser, hvordan Djigui er medvirkende til at påvirke, hvad assimilation og sekularisme betyder i den franske koloni. De forestillinger og rationaler, hans udsagn og handlinger er begrundet i, såvel som den sociale orden, der omgiver ham, er en del af den udsigelsesagens, der giver ordene betydning.

Lad os dernæst gå til mit andet eksempel. Når rekrutteringsteamet, der udspørger Barmi, tilsidesætter hans faglige kvalifikationer for i stedet at tale om muslimer, fem daglige bedestunder og svinekød, laver de umiddelbart et brud med den diskursive formation omkring jobsamtaler, der forudsætter, at man lægger vægt på faglige kvalifikationer og ikke bruger tid på at spørge ikke-troende ud om de religiøse ritualer, de jo ikke går op i. Set fra teamets synsvinkel kan deres tilsyneladende irrationelle handling forklares ved, at de taler ud fra en diskursiv formation, der sætter et matematisk lighedstegn mellem det at komme fra et land eller en region, der opfattes som arabisk og muslimsk, og det at skabe problemer på arbejdspladsen på grund af rituelle praksisser - også dem, der ikke er arbejdsrelaterede eller nødvendigvis angår nogen som helst andre (som fx spisevaner).

Rundt om i det omgivende samfund er der masser af politikere, meningsdannere, love og institutioner, der understøtter og er en del af denne komplekse og mangefacetterede diskursive formation, der derfor forekommer dem og store dele af det omgivende samfund at være fuldt ud legitim. At en sorthåret mand fra Mellemøsten skulle være ikke-troende og i den grad fagligt kvalificeret, at den kulturelle forskel (men hvor stor er den egentlig efter 15 år i Danmark?) bliver ganske irrelevant, ja, muligvis er spild af tid at tale om, den mulighed er ikke blot utænkelig, men aldeles ubegribelig, inden for denne logik. Ligesom det er tilfældet med Djiguis religiøse fundament, afhænger denne diskursive formation af en opretholdelse af et bestemt billede af, hvor religion er og bruges. ${ }^{7}$ Rekrutteringsteamets udsagn er med til at skabe rammerne og reglerne for, hvordan en jobsamtale foregår, og hvordan man interviewer en 'ny'dansker. Både teamets og jobkandidatens forestillinger og alle de implicerede diskursive formationer er en del af samtalens udsigelsesagens. 

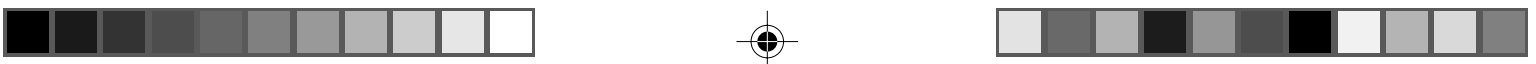

Men vi befinder os stadig på et overordnet plan. Lad os dernæst prøve at komme ned til det enkelte ord eller, som man siger i dele af lingvistikken og semiotikken, det enkelte tegn.

\section{Ordets dialogisme og tegnets anterioritet}

Bakhtin diskuterer ikke kun 'flersprogetheden', men også hvordan det enkelte ord betyder. Hvert ord indebærer en dialogisme. Med dette udtryk refererer Bakhtin til det forhold, at udsagnet - både i sin totalitet og i det enkelte ord indgår $\mathrm{i}$ et miljø af fremmede og mangfoldige sprog og ord, der allerede er i konstant forhandling om, præget af vurderinger og ændringer af, hvad der skal betyde hvordan. Udsagnet kan gå imod nogen, læne sig op ad andre, låne af en tredje osv. Det er opstået ud af en social dialog, og hvert ord har en bagage med af sociale dialoger, der allerede har tilskrevet det værdi og betydning (Bakhtin 1978:100). Vi genfinder altså den føromtalte sociale flersprogethed nede på det enkelte ords semiotiske niveau.

Litteraturkritikeren Homi Bhabha arbejder videre med denne problematik i sin artikel „DissemiNation“ (1990), der som titlen antyder diskuterer tegnet 'nation' med reference til Derridas dekonstruktivisme. Bhabha diskuterer ikke, hvad nationsbegrebet betyder, men hvordan det betyder, og opridser samtidig, på hvilken måde dette 'hvordan' får indvirkning på, hvad tegnene 'nation' og (det nationale) 'folk' refererer til. Bhabha forsøger at gøre rede for det, han kalder tegnets tid (op.cit. 308). I denne vending lægger han, hvad man kan kalde tegnets betydningstid, som ikke er serielt og kronologisk, men iterativt, fordi tegnet begynder at betyde, hver gang det udsiges. Hver gang ordet optræder, sker betydningstillæggelsen i sam- eller modspil med den sociale flersprogethed, som Bakhtin taler om. Men tegnets tid, betydningstiden, dækker hos Bhabha også over den sociale tidsopfattelse, som tegnet skriver sig ind i. Det vender jeg tilbage til lige om lidt.

Når Bhabha, der henviser eksplicit til Bakhtin (op.cit. 294-5), taler om henholdsvis betydningens og tegnets anterioritet (op.cit.310-1), medtænker han, at forhandlingen om, hvad et ord betyder, sker i talrige omgange (hver gang ordet udsiges), hvor tidligere betydninger og det, han kalder 'sociale og kulturelle videnspositioner' (op.cit. 310), kan anvendes, ignoreres eller eksplicit udnyttes. Derimod kan foregående betydninger ikke altid uden videre presses ind som en naturlig fortsættelse af en given ( $\mathrm{fx}$ national eller folkelig) tradition. Bhabhas pointe er, at for at forstå, hvad nationsbegrebet betyder i de tekster og udsagn, vi arbejder med, er det ikke tilstrækkeligt at tage højde for de historiske, sociale og materielle grundvilkår. Vi må også forstå den betydningsdannende temporalitet, udsigelsestemporaliteten, gennem hvilken tegnet og det begreb, det henviser til, får tillagt betydning. 

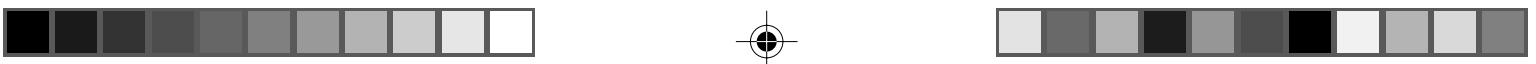

Og nu vender jeg så tilbage til den socialt funderede tidsopfattelse. Tegnene 'nation' og 'folk's betydninger fremkommer, ifølge Bhabha, på baggrund af en disjunktiv temporalitet, som er en del af disse tegns grundbetydning - i hvert fald i den moderne udsigelse af ordet (op.cit. 299). På den ene side har vi den iterative tid, som han kalder den performative tid. På den anden side har vi en pædagogisk fortælling, der taler for en kronologisk fremadskridende og vidensakkumulerende national tid. Han giver selv en fin forklaring:

Folket [som begreb og tegn] er ikke blot en reference til historiske begivenheder eller bestanddele i en patriotisk politisering af mennesket. Folket er også en kompleks retorisk og strategisk regulering af sociale referencer, i hvilken kravet om at kunne være repræsentativ medfører en krise i betydningsprocessen og i den implicitte diskursive henvendelse. Vi står altså over for en dobbelttid: Folket er en nationalistisk pædagogiks historiske 'genstand' (objekt), da det giver diskursen en autoritet, som beror på den forud givne eller indstiftede historiske oprindelse eller begivenhed. Men folket er også 'subjekter' i en betydningsproces, der må udviske enhver foregående eller oprindelig tilstedeværelse af nationsfolket for at kunne tydeliggøre et forbløffende og fundamentalt princip, nemlig folket, som den fortløbende proces, gennem hvilken det nationale liv indløses og tillægges betydninger i en gentagen og reproducerende proces (Bhabha 1990:297). ${ }^{8}$

De gentagne bud på, hvad nationen og dets folk er, kan understøtte og bekræfte den pædagogiske forestilling, men de kan også i lige så høj grad udfordre den. En sådan udfordring fra $\mathrm{fx}$ minoriteter vil fungere som et 'supplement' $\mathrm{i}$ den betydning, Derrida har tilskrevet ordet, dvs. at det opstiller sig selv som et muligt og/eller delvist alternativ til det, som det vil supplere, hvormed der skabes en potentiel forskydning eller destabilisering af betydningen. ${ }^{9}$ Der indskydes så at sige en overvejelse eller et dynamisk betydningsforhold mellem supplementet og det, som det skal supplere. Bhabhas pointe er, at minoriteter fungerer som supplementer i forhold til majoritetssamfund, idet de, gennem iterative hverdagshandlinger og ytringer, ikke udtrykker sig som direkte dialektiske modsætninger til majoritetssamfundet og dets anerkendte varianter, men at de snarere, ved at tilegne sig den dominerende diskurs, udfordrer dens pragmatiske konsensus ved at anvende den på nye måder og lade ord og begreber henvise til andre handlinger og forståelser af tid og rum, end hvad majoritetssamfundet gør (op.cit. 305-6).

Lad mig nu vende tilbage til mine to oprindelige eksempler. Når man foretager en analytisk præcisering ud fra ordets dialogisme og tegnets anterioritet, er der altså tale om to niveauer: Dels har man blik for et givet ords eller begrebs mange forskellige betydninger, alt efter den sociale og historiske kontekst, dels har man blik for tegnets tid, altså at det giver sig til at betyde, hver gang det udsiges, men at det samtidig enten bekræfter eller bryder med en social tidsopfattelse, der er 

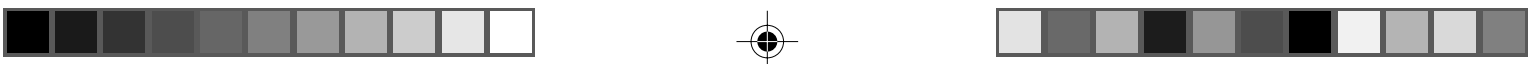

knyttet sammen med dets referent. Vi så, at Djigui ikke hørte Hérauds henvisning til historiens forløb som en bekræftelse på uafvendelig fremadskridende kronologisk historisk tid. Malinkésamfundets tidsopfattelse og historiske skæbne er helt og aldeles i Allahs hænder. Historikerens rolle er ikke at skabe en fremadskridende fortælling, men hele tiden at oversætte det nye til et sprog, der sikrer social sammenhængskraft med henvisning til Allah og de bærende institutioner og traditioner, hvor common sense-ordsprog (der ikke nødvendigvis er religiøse) er af stor betydning. Med andre ord er det ikke den pædagogiske kronologiske tid, der er det bærende fundament for, hvad tegnet 'histoire' betyder i Djiguis kongedømme. Det er derimod en performativ og iterativ opfattelse af tid og rum. Gentagne ritualer og udsigelse af fortællinger, der kan indskrive mening i nye fænomener som assimilation og sekularisme, er den dominerende diskursive form i kongens magtudøvelse. Man kan derfor også spørge sig selv, om man ikke her bør flytte adjektivet 'pædagogisk', så det i stedet kvalificerer den performative og iterative tid frem for den kronologisk fremadskridende.

Imidlertid kan jeg kun præcisere denne tidsforståelse og forhandlingen af den, fordi jeg kender tegnet histoires anterioritet i det frankofone Afrika, en anterioritet, der altså implicerer både europæiske og afrikanske historiografiske traditioner. En af romanens store kvaliteter er, at når Héraud siger 'historiens forløb', og Djigui vælger at lade det være op til Allah, er den bagvedliggende pragmatiske konsensus kontrapunktisk, fordi vi som læsere ikke får påduttet, hvis historieopfattelse der er den 'mest sande'. I stedet viser romanen os det ene eksempel efter det andet, hvor forskellige former for pragmatisk konsensus eksisterer side om side, griber ind $i$ hinanden og bliver del af den samme sociale og politiske kultur, nemlig den koloniale, uden at parterne nødvendigvis forstår hinanden til bunds. Romanen er dermed ikke blot en gengivelse af mødet mellem tradition og modernitet, den er først og fremmest et nærstudie af de komplekse kulturelle oversættelsesdynamikker, der gemmer sig bag personernes forestillinger om, hvad tegnene 'tradition' og 'modernitet' egentlig betyder i den præcise kontekst, de befinder sig i.

Vi ved ikke, hvordan rekrutteringspersonalet har oplevet situationen, og om de er enige i Barmis udlægning. Barmi er ikke troende, men er åbenbart blevet interviewet, som om han var. I Barmis tilfælde forekommer det mig derfor relevant at fokusere på ordet og tegnet 'muslim', eftersom det synes at være muslimske ritualer, der skabte støj på den pragmatiske konsensuslinje under jobsamtalen. Ved at se på tegnet 'muslim's anterioritet i den offentlige diskurs og i det erfaringsgrundlag, som rekrutteringsteamet og Barmi har, kan vi opstille nogle hypoteser om, hvad der er gået skævt (jobkandidaten udvandrer fra et interview), og måske derfra formulere nogle anbefalinger til fremtidige situationer. 

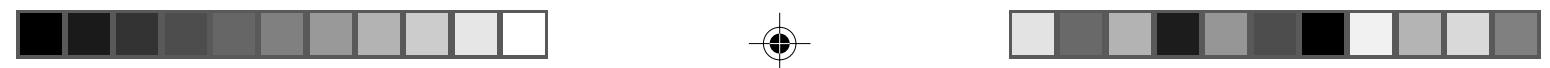

For rekrutteringsteamet betyder 'muslim' åbenbart potentielt problemer på baggrund af den diskursive formation, jeg nævnte tidligere. Vores hypotese kan derfor være, at rekrutteringspersonalet ingen begrebsmæssig forudsætning har for at kunne forstå den mand, der står foran dem. De har tilsyneladende ingen viden om, at der er betydelige mindretal af kristne i de lande og regioner, der oftest omtales som muslimske i de danske medier. De har heller ingen viden om de mange ikke-troende folk i og fra sådanne områder, ej heller ved de, at mange ikketroende eller ikke-praktiserende fra og i disse lande forholder sig lige så eller mere distanceret til religion end kulturkristne danskere, der går i kirke et par gange om året.

Hvad så med Barmis forståelse af 'muslim' i denne situation? Barmi læser jo også aviser, og han har over 100 afslag bag sig. Han ved godt, at han har oddsene imod sig, ligesom den kvindelige kandidat til en topchefstilling ved det. Om hans generelle forståelse af, hvad en muslim er, stemmer overens med rekrutteringsteamets, skal her være usagt. Pointen er, at han slet ikke opfatter sig som muslim. „Det handlede slet ikke om mig”, siger han i artiklen. Nej, spørgsmålene handlede om nogle forestillinger og forbehold i rekrutteringsteamet, som Barmi desværre ikke så sig i stand til at indgå i dialog om. Uanset hvilken identitetskategori der måtte være meningsgivende for Barmi selv, er og bliver pointen, at han i rekrutteringsteamets øjne har taget sig ud som en muslim, fordi dette tegns anterioritet $\mathrm{i}$ den diskursive formation om muslimer ofte refererer til indvandrere fra bestemte steder i verden, og altså også Iran. 15 års deltagelse i den danske fremadskridende historie er ikke tilstrækkeligt til at tilsidesætte den iterative repræsentation af mellemøstlige indvandrere som muslimer og potentielt problematiske. Barmi nægter at anerkende eller forstår simpelthen ikke den pragmatiske konsensusopfattelse af hans person. Rekrutteringsteamet på sin side evner åbenbart heller ikke at argumentere for relevansen i deres spørgsmål. Derfor brister kommunikationen

Man kunne også vælge at se på tegnet 'jobsamtale'. Her har Barmi muligvis overset, at man ud over at se på de faglige kvalifikationer også bruger samtalen til at vurdere personlige egenskaber, 'kemi', og på hvilken måde kandidaten vil passe til og komplementere dem, han skal arbejde sammen med. Det er muligt, at rekrutteringsteamet har stillet disse spørgsmål for at give Barmi en anledning til netop at vise sin forskellighed fra det stereotype billede, der ellers herskede på virksomheden på baggrund af en enkelt dårlig erfaring og en magtfuld diskursiv formation. Men da han ikke anerkender eller forstår rekrutteringsteamets bevæggrunde for, hvordan de ser ham som 'tegn', reagerer han med vrede og afmagt. 

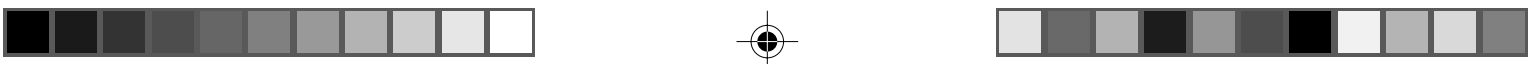

\section{En foreløbig overvejelse over kontrapunktisk tilgang til kulturmøder i praksis}

Mit sidste eksempel viser, at jobkandidater såvel som rekrutteringspersonale må være sig bevidst om de diskursive formationer - man kan måske kalde dem for 'meningsdannende sociale forestillinger og praksisser' i denne sammenhæng der er fremherskende i samfundet omkring arbejdspladsens, dens medarbejderes og jobkandidatens sociale identitet. Som vi har set i Kouroumas roman, er det ikke afgørende, om disse fremstillinger er sande, men at de har social gennemslagskraft. Man kan ikke på forhånd regne med, at de andre ser en, som man gerne vil ses, og man må forholde sig strategisk til de forhold, der kunne gå en imod. Har man på forhånd mulighed for at forberede sig på, hvilke forestillinger, hvilke diskursive formationer der vil være på spil i et givent job og i en jobsamtale, kan man planlægge en kontrapunktisk tilgang. Heri ligger, at man ikke nødvendigvis går direkte til modangreb på de indfaldsvinkler og synspunkter, man er uenig i, men at man hele tiden komplementerer dem med andre indfaldsvinkler eller synspunkter, der $\mathrm{g} \emptyset \mathrm{r}$, at det kritiske synspunkt ikke står alene og ikke får monopol på, hvordan samtalen skal forløbe.

En anden væsentlig pointe er, at man ikke nødvendigvis behøver at søge fuldkommen transparens og gensidig forståelse. ${ }^{10}$ Megen kulturel oversættelse foregår in medias res og overrumpler os ved, at vi skal oversætte noget, vi givetvis ikke helt kan gennemskue.

Lad os konkretisere det ud fra Barmis eksempel. Hvis man som jobkandidat finder, at en jobsamtale bygger på et problematisk eller ufordelagtigt grundlag, kan man vælge at spørge direkte og analytisk til de spørgsmål, man får, eller selv påpege, at man også har vigtige informationer, som bør komme med i betragtning. Hermed går man ind og præger aktivt den udsigelsesagens, der skaber betydning i situationen, i stedet for at affinde sig med den, som intervieweren og konteksten med de implicitte diskursive formationer skaber.

Magtforholdet i en jobsamtale er dog aldrig lige. Det kræver sit at mobilisere det nødvendige analytiske overskud til at vende fordomme imod sig til en gunstig platform, hvorfra man kan præsentere konstruktive overraskelser, og det sker sjældent i jobsamtaler. Den postkoloniale litteratur, men såmænd også andre litterære værker, giver indsigt i, hvor stærkt udgrænsende diskursive formationer kan ramme både den enkelte og forskellige sociale grupper, og hvor svært det kan være at fastholde troen på sig selv som menneske og ikke som det 'tegn', de andre taler til en ud fra. Det kan ses hos så forskellige forfattere som Martin A. Hansen, H.C. Andersen, Tove Ditlevsen, Michael Strunge og mange flere. Men det er også muligt at tale magten imod uden at gå fuldt ind på dens præmisser. Det gjorde cubanske Alejo Carpentier i sin teoretiseren af lo real maravilloso 

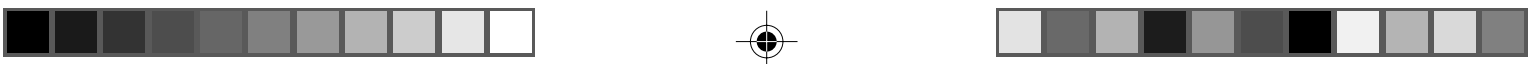

som et modtræk til Franz Rohs og surrealismens magiske realisme. ${ }^{11} \mathrm{Og}$ det gjorde Nelson Mandela, da han i fængslet på Robben Island gjorde oprør ved i skjul at undervise ikke kun sine medfanger, men også sine fangevogtere.

\section{Afrunding}

Overordnet set tjener de præsenterede begreber mindst to formål $i$ en analyse og håndtering af et kulturmøde.

For det første udgør de redskaber, der gør det muligt at gå analytisk til værks, idet man har mulighed for at kortlægge formen og graden af den kommunikation, der foregår i det, der enten på forhånd eller efterfølgende begrebsliggøres som et kulturmøde: Hvem får sagt hvad i løbet af mødet? Hvilke diskursive formationer er de mest fremtrædende? Hvilke anterioriteter forstås de centrale emner ud fra, og hvilke forties? Blev der dannet en form for fælles pragmatisk konsensus og ud fra hvilket - måske kontrapunktiske - grundlag? Hvad var magtforholdet mellem parterne, og hvilke sprog og erfaringer havde de til deres rådighed?

Bemærk, at man ikke konkluderer noget ud fra identitetskategorier, men ud fra de enkelte parters videns- og argumentationsgrundlag. Man undgår at fastlåse de involverede parter i politisk korrekte eller ukorrekte kategorier og får i stedet mulighed for at undersøge, hvilke forudsætninger der tales ud fra. Dermed får de involverede parter mulighed for at forholde sig selvreflekterende og analytisk til deres egne måder at virke i kulturmødet på.

Den anden erkendelsesmæssige gevinst er knyttet til de kollektive identitetstegns (som fx 'folk' og 'nation') disjunktive temporalitet. Denne tilgang gør, at uenighed og forhandling om, hvad de egentlig refererer til, normaliseres og afdramatiseres. 'Nation', 'folk' (og 'kultur') refererer ikke kun til en given intern konformitet og homogenitet, som forskellige grupper i samfundet kæmper om at have retten til at definere (kulturkamp). Begrebsliggørelsen af den disjunktive temporalitet giver os mulighed for at træde et skridt tilbage og anskue betydningen af 'folk' og 'nation' analytisk og ikke ideologisk. Det bliver nemlig tydeligt, at 'nation' og 'folk' også henviser til de måder, hvorpå mennesker håndterer blandt andet heterogenitet og foranderlighed ved at gøre nogle former for foranderlighed attråværdige (fremskridt, udvikling, nyskabelse, innovation), mens andre udgrænses som truende og negative (middelalderlig, tilbagestående, primitiv, lovløs).

Som i Djiguis kongerige har også Danmark sine meningsdannere, der forsøger at oversætte det nye og det anderledes ind i allerede eksisterende kategorier for social acceptabel adfærd. Uanset hvilket politisk ståsted vi måtte have, så forhindrer underforståede og indforståede hierarkiske forestillinger om forskellige kulturfællesskaber os i at opnå viden om de mange forskellige former for social 
praksis, der dannes inden for og på tværs af identitetsgivende kulturfællesskaber. Oversættelsen af det nye og det anderledes udfolder sig ikke kun gennem, hvad nogle opfatter som identitetsfællesskabets uafvendelige fremadskridende historiske udvikling, men består også af hvert enkelt individs - om hun så er 'majoritetsdansker' eller 'minoritetsdansker' - gentagne hverdagshandlinger. Den analytiske udfordring og mulige gevinst ved at indtænke den disjunktive temporalitet består netop i at tænke disse to aspekter - eller temporaliteter - som sameksisterende, hver gang vi giver os i kast med at kommentere eller analysere kulturmøder, fordi vi hele tiden må forholde os til, hvordan og på hvilken baggrund det enkelte menneske i den konkrete situation opfatter og oversætter det nye, det anderledes og foranderlige ind i sit eget hverdagsliv.

\section{Noter}

1. Se fx Jørgen Bæk Simonsens historiske gennemgang af danskernes syn på muslimer (Simonsen 2004). Se også Øystein Gaasholts og Lise Togebys kortlægning af danskernes holdning til flygtninge og indvandrere i perioden 1970-1993. Et gennemgående træk er vægten på kulturforskelle, hvor muslimer anses for at være en 'fare' (Gaasholt \& Togeby 1996:41). Jørgen Goul Andersen giver desuden en detaljeret redegørelse for forskningen på området herunder Togebys og andres opfølgende forskning (Andersen 2002).

2. Georges Balandier Une anthropologie des moments critiques (Paris: EHESS, 1996) eller Civilisés, dit-on (Paris: PUF, 2003). Cathrine Coquery-Vidrovitch Etre étranger et migrant en Afrique au XXe Siecle: Enjeux identitaires et modes d'insertion (Paris: L'Harmattan, 2003). Bernard Mouralis République et Colonie, entre mémoire et histoire (Paris: Présence africaine, 1999). Jean-Pierre Dozon Frères et sujets, La France et l'Afrique en perspective (Paris: Flammarion, 2003). For alle fires vedkommende har de bidraget med flere væsentlige bøger inden for feltet end de her anførte, hvoraf flere er oversat til engelsk. Om afrikanske soldaters krigsdeltagelse i 1. og 2. Verdenskrig, se foruden de ovennævnte også Myron Echenbergs uomgængelige og yderst veldokumenterede Colonial Conscripts (Portsmouth, London: Heinemann, James Currey, 1991).

3. „On refuse le droit de vote à ceux qui ne sont pas 'français', en même temps qu'on conteste 'l'enracinement' de ceux qui le sont." http://www.indigenes-republique.org/spip.php?article1 26-10-07.

4. Jævnfør blandt andet Madeleine Borgomanos og Michel Haussers analyser af Kouroumas romaner. Madeleine Borgomano Ahmadou Kourouma. Le 'guerrier' griot (Paris \& Montréal: L'Harmattan, 1998) og Des hommes ou des bêtes? Lecture d'En attendant le vote des bêtes sauvages d'Ahmadou Kourouma (Paris: L'Harmattan, 2000). Michel Hausser „Monnè, outrages et défis à la narration?" (i Voix nouvelles du roman africain, Daniel Delas \& Danielle Deltel (eds.), RITM, 1994, no. 7).

5. Mine teoretiske referencer oplyses og anvendes undervejs. På et overordnet plan inden for dansk forskning står jeg især i gæld til Harly Sonne og Christian Grambyes og til dels John Thobo-Carlsens arbejde med udsigelse, ligesom Per Aage Brandts semiotiske modeller også har sat sine spor.

6. Saids tilgang er her i tråd med Pierre Machereys 'symptomatiske læsning', men hos Said er det ikke indskrevet i en søgen efter beviser på 'falsk ideologi' eller méconnaissance de soi-même 

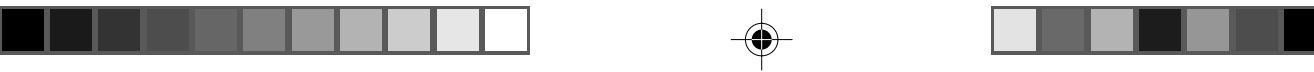

(Macherey 1966:154). Her er nærmere tale om en tekstanalytisk tilgang, som giver indsigt i fortællingens måde at betyde på uden nødvendigvis at forklare dens udeladelser efter en bestemt forudfattet ideologi.

7. At sekulære forståelser af, hvad religion er, og hvor dens plads i samfundet bør være, slet ikke er så entydige endda, diskuteres blandt andet i flere af den tyske filosofs Jürgen Habermas' udgivelser fra $2001 \mathrm{og}$ frem.

8. Bhabha foregiver ikke selv at have udtænkt denne tilsyneladende paradoksale tvedeling $\mathrm{i}$ nationsbegrebets betydning, men henviser til blandt andet Ernest Renans, Ernest Gellners og Partha Chatterjees argumenter ud fra lignende observationer. Originaliteten ved Bhabhas argument er, at han binder denne tvedeling tættere sammen med udsigelseshandlingen og med den sociale praksis, der bekræfter eller udfordrer hegemoniske forestillinger om det nationale fællesskab.

9. Bhabha henviser til Jacques Derridas Of Grammatology (oversat af G.C. Spivak, Baltimore, MD: Johns Hopkins University Press, 1976:144-5). Se eventuelt også Jacques Derrida De la grammatologie (Paris: Éditions de Minuit, 1967:208-14).

10. Her er der inspiration at hente hos den martinikanske filosof og forfatter Édouard Glissant, der igen er stærkt inspireret af den amerikanske romanforfatters William Faulkners personbeskrivelser. Glissant har især skrevet om kulturmøder i Caribien og sætter spørgsmålstegn ved det givende i at ville forstå den Anden fuldt ud. Empati og samarbejde fordrer ikke nødvendigvis en fuldstændig transparens (se Le Discours antillais, 1982 (oversat Caribbean Discourse), og Poétique de la Relation, 1990 (Poetics of Relation)).

11. Se fx Carpentiers tekster „The Baroque and the Marvelous Real“ og „On the Marvelous Real in America" (I Magical Realism. Theory, History, Community, Lois Parkinson Zamora \& Wendy B. Faris (eds.), Durham \& London: Duke University Press, 1995:75-108).

\section{Litteratur}

Andersen, Jørgen Goul

2002 Danskernes holdninger til indvandrere. En oversigt. AMID Working Paper Series 17. http://www.amid.dk/pub/papers/AMID_17-2002_Goul_Andersen.pdf (besøgt 7.6.07).

Bakhtin, Mikhail

1978 [1975] Esthétique et théorie du roman. Paris: Gallimard.

Benveniste, Émile

1966 Problèmes de linguistique générale. Bind II. Paris: Gallimard.

Bhabha, Homi K.

1990 DissemiNation: Time, Narrative, and the Margins of the Modern Nation. I: H. Bhabha (ed.): Nation and Narration. London: Routledge.

Bojsen, Heidi

2006 „Guerrier“ dans un monde postcolonial. Une etude de la production littéraire du sens dans des oeuvres choisies de Patrick Chamoiseau et d'Ahmadou Kourouma. Ph.d.-afhandling. Københavns Universitet.

Bojsen, Heidi \& Ingemai Larsen

2003 Narrating Postcolonial Nations: Reading Homi Bhabha's Notions. I: Hans Lauge (ed.): Changing Philologies II: Interdisciplinarity and Language Studies.

København: Museum Tusculaeum. 
Dozon, Jean-Pierre

2003 Frères et sujets. La France et L'Afrique en perspective. Paris: Flammarion.

Ducrot, Oswald

$1984 \quad$ Le dire et le dit. Paris: Éditions de Minuit.

Foucault, Michel

1969 L'archéologie du savoir. Paris: Éditions de Gallimard.

1971 L'ordre du discours. Paris: Éditions de Gallimard.

Gardiner, Michael

1992 The Dialogics of Critique. M.M. Bakhtin and the Theory of Ideology. London \& New York: Routledge.

Gaasholt, Øystein \& Lise Togeby

1996 I syv sind. København: Politica.

Kourouma, Ahmadou

1990 Monnè, outrages et défies. Paris: Éditions du Seuil (Points).

Loveless, Lotte Edberg

2003 Giv aldrig op! Integration gennem arbejde. Arbejdsmarkedsafdelingen, Århus

Kommune.

Machery, Pierre

1966 Pour une théorie de la production littéraire. Paris: Maspero.

Saada, Emmannuelle

$2003 \quad$ Citoyens et sujets de l'empire français. Les usages du droit en situation coloniale.

Genèse 53:4-24.

Said, Edward

1994 Culture and Imperialism. London: Vintage.

Simonsen, Jørgen Bæk

2004 Islam set med danske øjne: Danskernes syn på islam gennem 1000 år.

København: Akademisk Forlag. 